\title{
Status of Citrus tristeza virus (CTV) in Peninsular Malaysia
}

\author{
Kavous Ayazpour ${ }^{1}$, Kamaruzaman Sijam $^{1 *}$, Ganesan Vadamalai ${ }^{1}$, Hawa Jaafar ${ }^{2}$ \\ ${ }^{1}$ Plant Protection Department, Faculty of Agriculture, University Putra Malaysia, 43400, Malaysia. \\ ${ }^{2}$ Crop Science Department, Faculty of Agriculture, University Putra Malaysia, 43400, Malaysia.
}

Accepted 18 February, 2011

\begin{abstract}
Citrus tristeza virus (CTV) is the most important viral disease of Citrus spp. and has a worldwide distribution. Results of ELISA and PCR showed that all Citrus varieties including Fortunella sp., Citrofortunella microcarpa and Citromelo in major citrus growing areas of Malaysia had a high infection rate with CTV. In most areas, pomelo however was free of infection, but in Cameron Highlands, we found some strains of CTV that were severe to Citromelo and pomelo. Phylogeny studies revealed that these strains were similar to CTV isolates from China and Japan and were very different from CTV isolates from USA and New Zealand.
\end{abstract}

Key words: Citrus tristeza virus, phylogeny analysis, strain, CP gene, Malaysia.

\section{INTRODUCTION}

Citrus (namely species and hybrids of genera Citrus, Fortunella and Poncirus) is an important commercial fruit crop worldwide with approximately 7 million hectare cultivated surface (Fagoaga et al., 2006). Most of the citrus cultivars are propagated by grafting on rootstocks. The use of infected grafting materials for nursery propagation is primarily responsible for the distribution of virus and virus-like diseases in citrus (Abbas et al., 2006). Viral pathogens are transmitted by insect vectors as well as grafting, and cause large economic loses (Nolasco et al., 2009; Roy et al., 2005a).

Citrus tristeza virus (CTV) is a member of the genus Closterovirus (Family, Closteroviridae), distributed worldwide and causes one of the most economically important diseases of Citrus spp. (Bar-Joseph et al., 1989; Che et al., 2001; Gowda et al., 2009; Lair et al., 1994; Narvaez et al., 2000; Satyanarayana et al., 2001). CTV particles are flexuous, threadlike and $2000 \mathrm{~nm}$ in length (Huang et al., 2004; Jiang et al., 2008; Ruiz-Ruiz et al., 2007). They contain a positive-sense, singlestranded genomic RNA about $20 \mathrm{~kb}$ (Che et al., 2002; Hilf et al., 1995; Huang et al., 2004; Ruiz-Ruiz et al., 2007) with a molecular weight of 6.3 to $6.9 \times 106$ (Bar-Joseph

*Corresponding author. E-mail: kayazpour@yahoo.com. Tel: 0060192210540 . Fax: 0060356860698. et al., 1985). The RNA contains 12 open reading frames (Che et al., 2002; Fagoaga et al., 2005; Narvaez et al., 2000; Satyanarayana et al., 2001) and encodes at least 19 proteins (Che et al., 2002, 2001; Huang et al., 2004; Satyanarayana et al., 2001). Two of these are capsid proteins of 25 and $27 \mathrm{kDa}$, which coat respectively about 95 and $5 \%$ of the virus length (Bar-Joseph et al., 1989; Jiang et al., 2008; Roy et al., 2005b; Ruiz-Ruiz et al., 2007). Members of Closteroviridae are unusual in their size, genomic composition and have a complex replication strategy (Che et al., 2002). CTV is phloemlimited and is transmitted in a semi-persistent manner by aphids such as Aphis gossypii (Bar-Joseph et al., 1989; Brown et al., 1988; Genc, 2005; Gottwald et al., 1999), Toxoptera citricida (Bar-Joseph et al., 1989; Broadbent et al., 1996; Brown et al., 1988; Gottwald et al., 1999; Roy et al., 2005b), Aphis spiraecola (Gottwald et al., 1999) and Toxoptera aurantii (Brown et al., 1988; Gottwald et al., 1999). T. citricida and $A$. gossypii are the most efficient vectors of CTV (Bar-Joseph et al., 1989; Brlansky et al., 2003; Brown et al., 1988; Gottwald et al., 1999; Roy et al., 2005b).

The virus is genetically and biologically diverse. Virus isolate, citrus cultivar, rootstocks, time of infection, and environmental conditions can affect the symptoms (Huang et al., 2004; Satyanarayana et al., 2001). A complex range of symptoms is produced under field conditions. There are three economically devastating field 
symptoms caused by CTV. The first is decline and death of trees grafted onto sour orange rootstock. The second is stem pitting of scions, regardless of rootstock (Broadbent et al., 1996; Garnsey et al., 1987; Genc, 2005; Gmitter et al., 1996; Satyanarayana et al., 2001). Trees affected with CTV stem pitting strains, have reduced fruit production and quality. A third type of symptoms can cause losses in tree nurseries termed 'seedling yellows'. Symptoms of seedling yellows are leaf chlorosis and stunting of sour orange, grapefruit and lemon seedlings (Ruiz-Ruiz et al., 2007).

Diagnosis of CTV infection was been performed indexing on sensitive indicator species for many years (Garnsey et al., 1987; Genc, 2005; Ruiz-Ruiz et al., 2007). Double stranded RNA (dsRNA) analysis can discriminate between some CTV isolates in infected plants (Pappu et al., 1993), but dsRNA pattern and pathogenicity are not necessary correlated (Moreno et al., 1990). Reaction with monoclonal (Albiach-Marti et al., 2000a; Bar-Joseph et al., 1997; Genc, 2005; Permar et al., 1990; Peroni et al., 2009; Rocha-Pena and Lee, 1991; Ruiz-Ruiz et al., 2007; Vela et al., 1986) and polyclonal antibodies (Albiach-Marti et al., 2000a; BarJoseph et al., 1997; Lair et al., 1994; Rocha-Pena and Lee, 1991; Ruiz-Ruiz et al., 2007), dsRNA (Dodds and Bar-Joseph, 1983; Korkmaz, 2002; Yang et al., 1999) molecular hybridization with complementary DNA (Rosner and Bar-Joseph, 1984) or RNA probes (Narvaez et al., 2000), or reverse transcription followed by PCR amplification (RT-PCR) have been successfully used for quick and sensitive detection and characterization of CTV (Ruiz-Ruiz et al., 2007).

Decline and death of most Citrus spp. grafted on sour orange (Citrus aurantium L.) can be avoided by using rootstocks resistant or tolerant to CTV (Dominguez et al., 2000). Some species, such as Mexican lime (Citrus aurantifolia), are very sensitive to CTV infection and show disease symptoms with most CTV strains, whereas others, such as grapefruit and sweet orange (Citrus sinensis), are affected only by severe strains. Although sour orange is sensitive as a rootstock, seedlings accumulate virus at low titer with most CTV isolates. General resistance to CTV had been observed in trifoliate orange (Poncirus trifoliata (L.) Raf.), and resistance to some isolates occurs in Pomelo ( $C$. grandis) and kumquat (Fortunella crassifolia) (Fagoaga et al., 2005). In Citrus growing areas where severe isolates of CTV are common, cross protection with mild strains (Lin et al., 2002) and coat protein (CP) mediated-resistance (Dominguez et al., 2002; Febres et al., 2008) can reduce yield losses (Dominguez et al., 2000).

According to our observations and discussion with Citrus growers in Malaysia, the Citrus trees are propagated by air layering method in this country. There were some reports on occurrences of CTV in Peninsular Malaysia that needs attention, as information on CTV in Malaysia is limited; hence, this research was carried out to determine the distribution and host range of CTV in

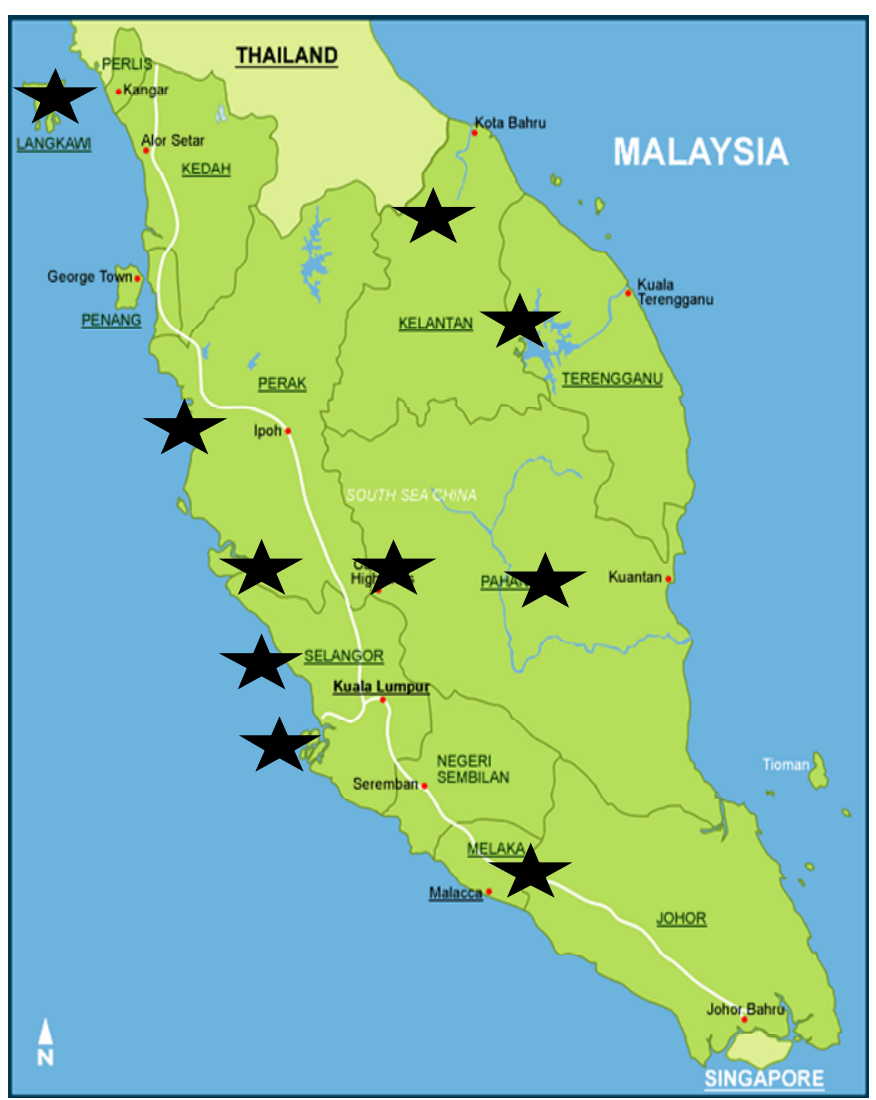

Figure 1. Outline map of Peninsular Malaysia showing the locations of samplings performed in the present work.

Peninsular Malaysia.

\section{MATERIALS AND METHODS}

\section{Plant materials}

Field samples were obtained randomly from 340 citrus trees, including C.aurantifolia, C. sinensis, C. maxima, C. reticulata, C. hystrix, Citrofortunella microcarpa, Fortunella sp., seven Poncirus sp. and 10 weeds including Passiflora foetida, Melothria pendula and Mikania micrantha growing in Selangor, Pahang, Johor, Terengganu, Perak and Kedah states in Malaysia (Figure 1). Mature shoots and leaves of Citrus plants were gathered from all sides of the trees pointing east, west, south and northward and then samples mixed for the test. Petioles, midrib of leaves and bark of shoots were used to prepare extractions for ELISA and extraction of total RNA for RT-PCR.

\section{ELISA determination}

To diagnose Citrus trees infected by CTV, direct double antibody sandwich (DAS) ELISA was performed (Rocha-Pena et al., 1991). In this study one polyclonal antiserum (Bioreba) was used. Extractions were prepared from $0.5 \mathrm{~g}$ of shoot barks, midribs and petioles in $5 \mathrm{ml}$ of $1 \times$ PBST buffer $(0.15 \mathrm{M} \mathrm{NaCl} ; 0.015 \mathrm{M}$ $\mathrm{NaH}_{2} \mathrm{PO}_{4} ; 0.05 \%$ Tween 20, pH 7.0). Positive reactions were defined as an $\mathrm{OD}_{405 \mathrm{~nm}}$ two times higher than negative control. 


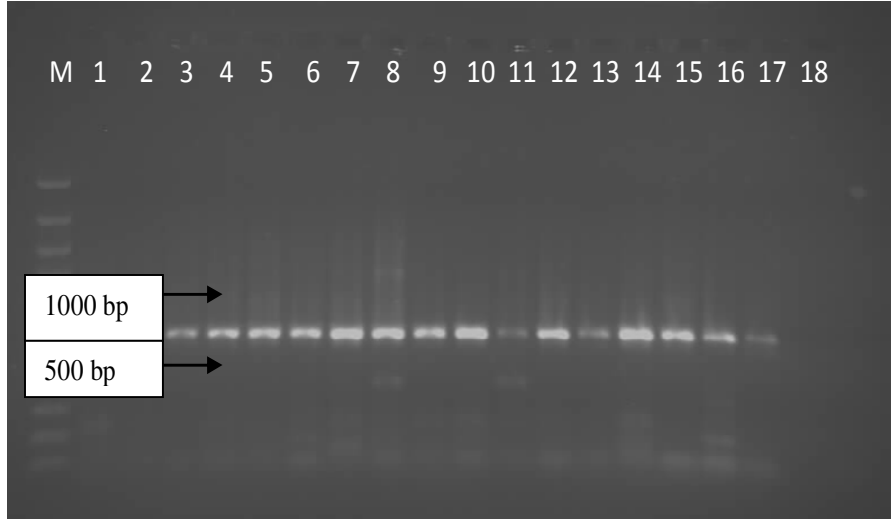

Figure 2. PCR product profile of some Malaysian Citrus tristeza virus isolates in $1.2 \%$ agarose gel. $\mathrm{M}$, molecular marker; line 1 to 17 , infected plants; line 18, healthy plant.

\section{Nucleic acid extraction from citrus tissues}

Total RNA (tRNA) was extracted from $0.2 \mathrm{~g}$ of shoot barks, midribs and petioles. First tissues were pulverized with liquid nitrogen by pestle and mortar and then collected in $1.5 \mathrm{ml}$ sterile eppendorf tube. Each sample was suspended in $400 \mu$ TES buffer $(100 \mathrm{mM}$ Tris- $\mathrm{HCl} \mathrm{pH} \mathrm{8.0;} 2 \mathrm{mM}$ EDTA; $2 \% \mathrm{w} / \mathrm{v}$ SDS) and $400 \mu \mathrm{l}$ phenol/chloroform/isopropanol (25/24/1) and shook vigorously for $10 \mathrm{~min}$. After centrifugation (14000 rpm) for $10 \mathrm{~min}$, the supernatant $(400 \mu \mathrm{l})$ was treated with $200 \mu \mathrm{l}$ ethanol $(99.8 \%)$ and used in RNeasy mini kit and tRNA extracted according to the manufacturer's instructions and was used as template for the amplification of the coat protein (CP) gene of CTV.

\section{Primers}

For amplification of the complete CP cistron (672 bp) of CTV, two primers were used based on Jiang et al. (2008) report. The sense primer was CP1: 5'-ATG-GAC-GAC-GAA-ACA-AAG-AA-3' and the anti sense primer was CP2: 5'-TCA-ACG-TGT-GTT-GAA-TTT-CC$3^{\prime}$.

\section{cDNA synthesis and polymerase chain reaction amplification}

By using tRNAs extracted from citrus tissues as templates and CP2 as primer cDNA was synthesized. The total reaction volume was 40 $\mu \mathrm{l}$, which contained $50 \mathrm{mM}$ Tris- $\mathrm{HCl}(\mathrm{pH} 8.3), 50 \mathrm{mM} \mathrm{KCl}, 4 \mathrm{mM}$ $\mathrm{MgCl}_{2}, 10 \mathrm{mM}$ DTT, $0.2 \mathrm{mM}$ each of the four dNTPs, $1 \mu \mathrm{m} \mathrm{CP} 2,20$ $\mathrm{U}$ reverse transcriptase, and $18.75 \mu \mathrm{l}$ extracted RNA. First tRNA and primer were mixed gently, heated for $10 \mathrm{~min}$ at $65^{\circ} \mathrm{C}$, and then immediately cooled on ice. After this, other materials were added and the contents were mixed gently and incubated at $25^{\circ} \mathrm{C}$ for 10 $\min , 42^{\circ} \mathrm{C}$ for $60 \mathrm{~min}$ and $72^{\circ} \mathrm{C}$ for 10 min., respectively. The PCR amplification was performed in $25 \mu \mathrm{l}$ of reaction mixture containing $10 \mathrm{mM}$ Tris- $\mathrm{HCl}(\mathrm{pH} 8.3), 50 \mathrm{mM} \mathrm{KCl}, 0.05 \mathrm{mM}$ each of the four dNTPs, $2 \mathrm{mM} \mathrm{MgCl} 2,0.3 \mu \mathrm{M}$ of each primer (CP1, CP2), $1.25 \mathrm{U}$ Taq DNA polymerase (iNtRON Biotechnology) and 1 to $4 \mu \mathrm{l}$ of RT mixture. The PCR cycling profile consisted of one cycle at $94^{\circ} \mathrm{C}$ for $5 \mathrm{~min}$., followed by 35 cycles of $94^{\circ} \mathrm{C}$ for $30 \mathrm{~s}, 56^{\circ} \mathrm{C}$ for $1 \mathrm{~min}$, and $72^{\circ} \mathrm{C}$ for $1 \mathrm{~min}$, with a final extension step at $72^{\circ} \mathrm{C}$ for $10 \mathrm{~min}$. PCR amplified fragments were separated in $1.2 \%$ agarose gels in Trisborate (TBE) buffer ( $89 \mathrm{mM}$ Tris; $89 \mathrm{mM}$ boric acid; two mM EDTA, $\mathrm{pH}$ 8.3). After electrophoresis, the gels were stained in $0.5 \mu \mathrm{g} / \mathrm{ml}$
Table 1- Percentage CTV infection from survey of plants in Peninsular using ELISA and PCR tests.

\begin{tabular}{lccc}
\hline Variety & $\begin{array}{c}\text { Total } \\
\text { sample }\end{array}$ & $\begin{array}{c}\text { No. infected } \\
\text { with CTV }\end{array}$ & \% infection \\
\hline C. sinensis & 21 & 17 & 80.95 \\
Lemons & 7 & 4 & 57.14 \\
Citrumelo & 3 & 2 & 66.67 \\
C. limonia & 2 & 2 & 100 \\
C. hystrix & 22 & 21 & 95.45 \\
C. aurantifolia & 62 & 59 & 95.16 \\
C. reticulata & 66 & 44 & 66.67 \\
Fortunella sp. & 15 & 15 & 100 \\
C. microcarpa & 50 & 50 & 100 \\
Poncirus & 7 & 0 & 0 \\
Mikania & 3 & 0 & 0 \\
micrantha & 3 & 0 & 0 \\
Melothria & 3 & 0 & 0 \\
pendula & & 0 & 2.02 \\
$\begin{array}{l}\text { Passiflora } \\
\text { foetida }\end{array}$ & 4 & 2 & \\
C. maxima & 92 & & \\
\hline
\end{tabular}

ethidium bromide and analyzed using $\mathrm{BIO}$ imaging system (Syngene). A 100 bp DNA Ladder (Fermentas) was used as a nucleic acid marker.

\section{RESULTS}

PCR results showed that primers CP1 and CP2 amplified a part of the genome of all isolates of CTV and produced a band of about $672 \mathrm{bp}$ in agarose gel electrophoresis (Figure 2). The results of CTV infection survey by using ELISA and PCR methods showed that the virus was present in all samples from different varieties of Citrus and related genera collected from Peninsular Malaysia (Table 1). This survey showed that in almost areas, all pomelo trees were free of virus infection, except for Cameron Highland areas where CTV was detected in both pomelo and citromelo trees. The sequences of the coat protein gene of these isolates were compared with some other isolates in the world. Phylogeny tree of these isolates in comparison with 10 isolates from other countries (Table 2) showed that AMC2 and AMC7 are very close to CT-W1, isolated from Poncirus in China and are close to NUagA isolate from Japan and ML12 isolate from China. They were grouped in one cluster. AMC6 and Bangalore isolates from India were placed in another cluster. Resistant break isolates (NZRB-M17, NZRB-G90 and NZRB-TH28) from New Zealand produced a completely separate cluster. These strains had been isolated from $P$. trifoliata. T36, T30 and T385 were grouped in another cluster and were the furthest from the others (Figure 3 ). 
Table 2. Citrus tristeza virus isolates used in this study for drawing phylogenic tree.

\begin{tabular}{lllll}
\hline Isolate & Pathogenicity or host & Accession number & Source & Reference \\
\hline T385 & Mild & Y18420 & Spain & (Vives et al., 1999) \\
T30 & Mild & AF260651 & Florida, USA & (Albiach-Marti et al., 2000b) \\
T36 & Quick decline & U16304 & Florida, USA & (Karasev et al., 1995) \\
NUagA & Seedling yellows and stem pitting & AB046398 & Japan & (Suastika et al., 2001) \\
Bangalore & Stem pitting & AF501867 & India & (Roy et al., 2003) \\
ML-12 & Stem pitting & EF028325 & China & (Jiang et al., 2008) \\
CT-W1 & Poncirus & FJ998191 & China & \\
NZRB-G90 & Poncirus & FJ525432 & New Zealand & (Harper et al., 2010) \\
NZRB-TH28 & Poncirus & FJ525433 & New Zealand & (Harper et al., 2010) \\
NZRB-M17 & Poncirus & FJ525435 & New Zealand & (Harper et al., 2010) \\
AMC2 & Citromelo & HQ012375 & Malaysia & \\
AMC6 & Pomelo & HQ012376 & Malaysia & \\
AMC7 & Pomelo & HQ012377 & Malaysia & \\
\hline
\end{tabular}

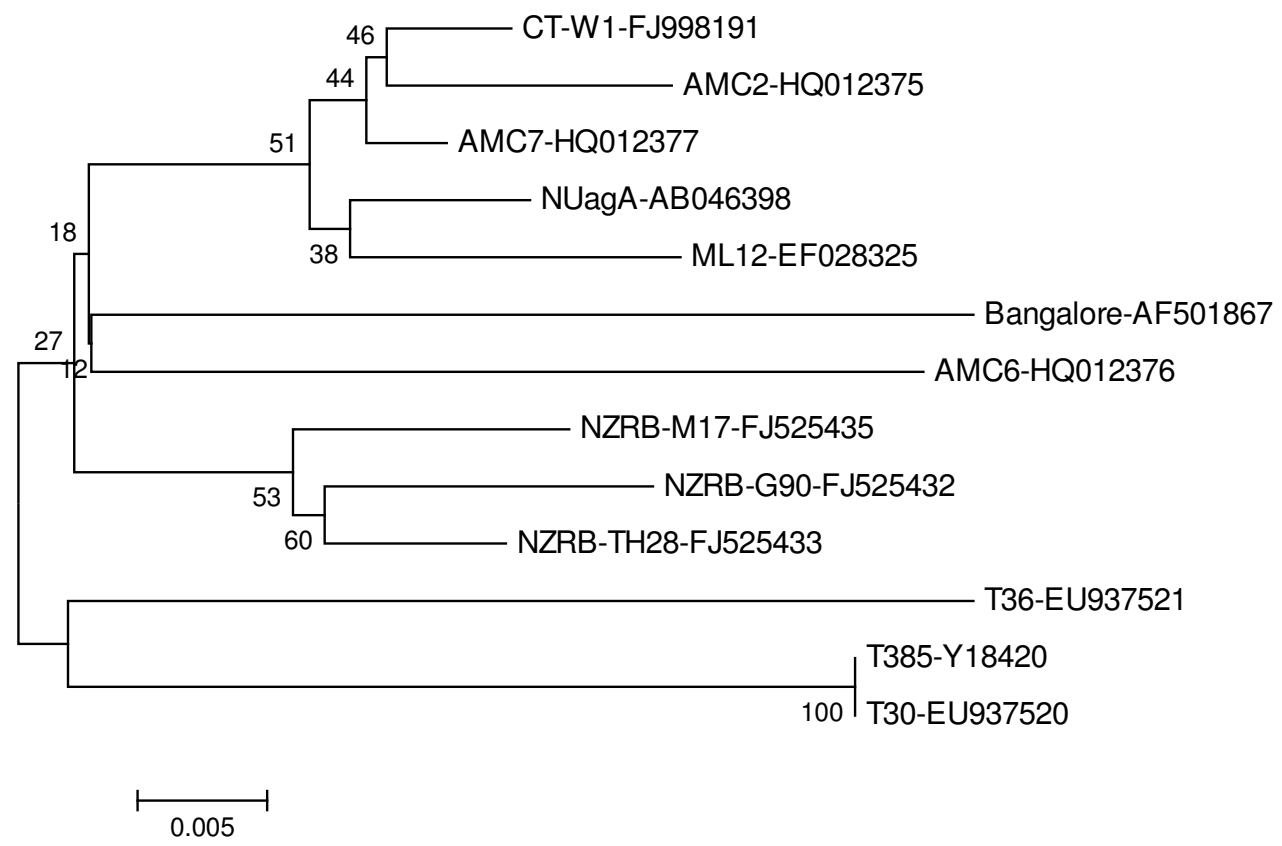

Figure 3. The bootstrap phylogenic tree of pomelo and Poncirus isolates of Citrus tristeza virus from Malaysia in comparison to 10 isolates from around the world using MEGA software version 4 (Tamura et al., 2007).

\section{DISCUSSION}

Results showed that the percentage of CTV infection in Citrus and relatives genera in Malaysia is very high but these plants were almost symptomless. No stem pitting and no vein clearing was observed. According to the statements of Satyanarayana et al. (2001) and Huang et al. (2004), it might be due to Citrus tristeza Virus strains or environmental conditions of Malaysia. Also, results of Garnsey et al. (1987) and Broadbent et al. (1996) confirm that propagation method of citrus in Malaysia can affects on appearance of CTV symptoms. However, further verification of the virulence status of this strains need using molecular characterization.

In Keluang area, virus infection was observed in three years old $C$. hystrix, $C$. aurantifolia and $C$. microcarpa trees which may indicate that these trees were propagated from CTV infected plant materials and infection was started from the off-farm source. Results of Table 1 showed that pomelo is free of CTV in the most 
areas of Malaysia that indicates resistance of pomelo to CTV which is confirmed by Fagoaga et al. (2005), but infected pomelos can be found in Cameron Highlands. We suppose that some aggressive strains have been present in Cameron highlands imported from other countries, since these samples were collected from the citrus collection of Malaysian Agricultural Research and Development Institute (MARDI) of Cameron Highlands. This area is quarantined and separated by natural conditions from the other citrus groves. So, inhibition of citrus budwoods, cuttings and seedlings transfer from Cameron Highlands to the other states of Malaysia is recommended.

\section{REFERENCES}

Abbas M, Khan MM, Mughal SM, Muhammad JJ, Abbas H (2006). Propagation of CTV-Free sweet orange (Citrus Sinensis) plants through micro budding technique. Pak. J. Bot., 38: 583-587.

Albiach-Marti MR, Guerri J, Cambra M, Garnsey SM, Moreno P (2000a). Differentiation of Citrus tristeza virus isolates by serological analysis of p25 coat protein peptide maps. J. Virol. Meth., 88: 25-34.

Albiach-Marti MR, Guerri J, Hermoso de Mendoza A, Laigret F, Ballester-Olmos JF, Moreno P (2000b). Aphid transmission alters the genomic and defective RNA populations of Citrus tristeza virus isolates. Phytopathol., 90: 134-138.

Bar-Joseph M, Filato V, Gofman R, Guang Y, Hadjinicolis A, Mawassi M, Gootwine E, Weisman Y, Malkinson M (1997). Booster immunization with a partially purified Citrus tristeza virus (CTV) preparation after priming with recombinant CTV coat protein enhances the binding capacity of capture antibodies by ELISA. J. Virol. Meth., 67: 19-22.

Bar-Joseph M, Gumpf DJ, Dodds JA, Rosner A, Ginzberg I (1985). A simple purification method for Citrus tristeza virus and estimation of its genome size. Phytopathol., 75: 195-198.

Bar-Joseph M, Marcus R, Lee RF (1989). The continuous challenge of Citrus tristeza virus control. Ann. Rev. Phytopathol., 27: 292316.

Brlansky RH, Damsteegt VD, Howd DS, Roy A (2003). Molecular analyses of Citrus tristeza virus subisolates separated by aphid transmission. Plant Disease, 87: 397-401.

Broadbent P, Brlanskey $\mathrm{RH}$, Indsto $\mathrm{J}$ (1996). Biological characterization of Australian isolates of CTV and separation of subisolates by single aphid transmission. Plant Diseases, 80: 329-333.

Brown LG, Denmark HA, Yokomi PK (1988). Citrus tristeza virus and its vectors in Florida, Fllorida department of agriculture and consumer services: Plant Pathology Circular, p. 4

Che X, Mawassi M, Bar-Joseph M (2002). A novel class of large and infectious defective RNAs of Citrus tristeza virus. Virology, 298: 133-145.

Che X, Piestun D, Mawassi M, Yang G, Satyanarayana S, Gowda S, Dawson WO, Bar-Joseph M (2001). 5'-coterminal subgenomic RNAs in Citrus tristeza virus-infected cells. Virology, 283: 374381.

Dodds JA, Bar-Joseph M (1983). Double-stranded RNA from plants infected with closteroviruses. Phytopathology, 73: 419-423.

Dominguez A, de Mendoza AH, Guerri J, Cambra M, Navarro L, Moreno P, Pena L (2002). Pathogen-derived resistance to Citrus tristeza virus (CTV) in transgenic mexican lime (Citrus aurantifolia (Christ.) Swing) plants expressing its p25 coat protein gene. Molecular Breeding, 10: 1-10.

Dominguez A, Guerri J, Cambra M, Navarro L, Moreno P, Pena L
(2000). Efficient production of transgenic citrus plants expressing the coat protein gene of Citrus tristeza virus. Plant Cell Reports, 19: 427-433

Fagoaga C, Lopez C, de Mendoza AH, Moreno P, Navarro L, Flores R, Pena L (2006). Post-transcriptional gene silencing of the p23 silencing suppressor of Citrus tristeza virus confers resistance to the virus in transgenic Mexican lime. Plant Mol. Biol., 60: 153-165.

Fagoaga C, Lopez C, Moreno P, Navarro L, Flores R, Pena L (2005). Viral-Like symptoms induced by the ectopic expression of the p23 gene of Citrus tristeza virus are Citrus specific and do not correlate with the pathogenicity of the virus strain. Molecular Plant-Microbe Interactions, 18: 435-445.

Febres VJ, Lee RF, Moore GA (2008). Transgenic resistance to Citrus tristeza virus in grapefruit. Plant Cell Reports, 27: 93-104.

Garnsey SM, Gumpf DJ, Roistacher CN, Civerolo E, Lee RF, Yokomi RK, Bar-Joseph M (1987). Toward a standard evaluation of the biologically properties of citrus tristeza virus. Phytophylactica, 19: 151-157.

Genc H (2005). A new method for the detection of minor populations of Citrus tristeza virus strains infecting single citrus trees. Turk. J. Agric. For., 29: 449-459.

Gmitter Jr FG, Xiao NY, Huang S, Hu XL, Garnsey SM, Deng Z (1996). A localized linkage map of the Citrus tristeza virus resistance gene region. Theor. Appl. Gen., 92: 688-695.

Gottwald TR, Gibson GJ, Garnsey SM, Irey M (1999). Examination of the effect of aphid vector population composition on the spatial dynamics of Citrus tristeza virus spread by stochastic modeling. Phytopathology, 89: 603-608.

Gowda S, Satyanarayana T, Folimonova SY, Hilf ME, Dawson WO (2009). Accumulation of a 5'proximal subgenomic RNA of Citrus tristeza virus is correlated with encapsidation by the minor coat protein. Virology, 389: 122-131.

Harper SJ, Dawson TE, Pearson MN (2010). Isolates of Citrus tristeza virus that overcome Poncirus trifoliata resistance comprise a novel strain. Archive Virol., 155: 471-480.

Hilf ME, Karasev AV, Pappu HR, Gumpf DJ, Niblett CL, Garnsey SM (1995). Characterization of Citrus tristeza virus sub-genomic RNAs in infective tissue. Virology, 208: 576-582.

Huang Z, Rundell PA, Guan X, Powell CA (2004). Detection and isolate differentiation of Citrus tristeza virus in infected field trees based on reverse transcription-polymerase chain reaction. Plant Dis., 88: 625-629.

Jiang B, Hong N, Wang G, Hu J, Zhang J (2008). Characterization of Citrus tristeza virus strains from southern China based on analysis of restriction patterns and sequences of their coat protein genes. Virus Genes, 37: 185-192.

Karasev AV, Boyko VP, Gowda S, Nikolaeva OV, Hilf ME, Koonin EV, Niblett CL, Cline K, Gumpf DJ, Lee RF, Garnsey SM, Lewandowski DJ, Dawson WO (1995). Complete Sequence of The Citrus tristeza virus Genome. Virology, 208: 511-520.

Korkmaz S (2002). Investigation of biological properties, doublestranded RNA patterns and antigen concentration in Citrus species infected with Citrus tristeza virus. Phytoparasitica, 30: 420-428.

Lair SV, Mirkov TE, Dodds JA, Murphy MF (1994). A single temperature amplification technique applied to the detection of Citrus tristeza viral RNA in plant nucleic acid extracts. J. Virol. Meth., 47: 141-152.

Lin Y, Rundell PA, Powell CA (2002). In situ immunoassay (ISIA) of field grapefruit trees inoculated with mild isolates of Citrus tristeza virus indicates mixed infections with severe isolates. Plant Disease, 86: 458-461

Moreno P, Guerri J, Munoz N (1990). Identification of Spanish strains of Citrus tristeza virus (CTV) by analysis of doublestranded RNAs (dsRNA). Phytopathology, 80: 477-482.

Narvaez G, Skander BS, Ayllon MA, Rubio L, Guerri J, Moreno P (2000). A new procedure to differentiate Citrus tristeza virus 
isolates by hybridisation with digoxigenin-labelled cDNA probes. J. Virol. Meth., 85: 83-92.

Nolasco G, Santos C, Silva G, Fonseca F (2009). Development of an asymmetric PCR-ELISA typing method for Citrus tristeza virus based on the coat protein gene. J. Virol. Meth., 155: 97-108.

Pappu H, Pappu S, Niblett C, Lee R, Civerolo E (1993). Comparative Sequence Analysis of The Coat Proteins of Biologically Distinct Citrus Tristeza Closterovirus Isolates. Virus Genes, 7: 55-264.

Permar TA, Garnsey SM, Gumpf DJ, Lee RF (1990). A monoclonal antibody that discriminates strains of Citrus tristeza virus. Phytopathology, 80: 224-228.

Peroni LA, Lorencini M, dos Reis JRR, Machado MA, StachMachado DR (2009). Differential diagnosis of Brazilian strains of Citrus tristeza virus by epitope mapping of coat protein using monoclonal antibodies. Virus Res., 145: 18-25.

Rocha-Pena MA, Lee RF (1991). Serological techniques for the detection of Citrus tristeza virus. J. Virol. Meth., 34: 311-331.

Rocha-Pena MA, Lee RF, Niblett CL (1991). Development of a dotimmunobinding assay for detection of Citrus tristeza virus. J. Virol. Meth., 34: 297-309.

Rosner A, Bar-Joseph M (1984). Diversity of Citrus tristeza virus strains indicated by hybridization with cloned cDNA sequences. Virol., 139: 189-193.

Roy A, Fayad A, Barthe G, Brlansky RH (2005a). A multiplex polymerase chain reaction method for reliable, sensitive and simultaneous detection of multiple viruses in citrus trees. J. Virol. Meth., 129: 47-55.

Roy A, Manjunath KL, Brlansky RH (2005b). Assessment of sequence diversity in the 5 '-terminal region of Citrus tristeza virus from India. Virus Res., 113: 32-142.

Roy A, Ramachandran P, Brlansky RH (2003). Grouping and comparison of Indian Citrus tristeza virus isolates based on coat protein gene sequences and restriction analysis patterns. Arch. Virol., 148: 707-722.
Ruiz-Ruiz S, Morenoa P, Guerri J, Ambros S (2007). A real-time RT-PCR assay for detection and absolute quantitation of Citrus tristeza virus in different plant tissues. J. Virol. Meth., 145: 96105.

Satyanarayana T, Bar-Joseph M, Mawassi M, Albiach-Marti MR, Ayllon MA, Gowda S, Hilf ME, Moreno P, Garnsey SM, Dawson WO (2001). Amplification of Citrus tristeza virus from a cDNA clone and infection of Citrus trees. Virology, 280: 87-96.

Suastika G, Natsuaki T, Teruii H, Kano T, lekp H, Okuda S (2001). Nucleotide sequence of Citrus tristeza virus seedling yellows isolate. J. Gen. Plant Pathol., 67: 73-77.

Tamura K, Dudley J, Nei M, Kumar S (2007). MEGA4: Molecular Evolutionary Genetics Analysis (MEGA) software version 4.0. Mol. Biol. Evol., 24: 1596-1599.

Vela C, Cambra M, Cortes E, Moreno P, Miguet J, Perez de San Roman C, Sanz A (1986). Production and characterization of monoclonal antibodies specific for citrus tristeza virus and their use for diagnosis. J. Gen. Virol., 67: 91-96.

Vives MC, Rubio L, Lopez C, Navas-Castillo J, Albiach-Marti MR, Dawson WO, Guerri J, Flores R, Moreno P (1999). The Complete Genome Sequence of The Major Component of a Mild Citrus Tristeza Virus Isolate. J. Gen. Virol., 80: 811-816.

Yang G, Che X, Gofman R, Ben-Shalmon Y, Piestun D, Gafny R, Mawassi M, Bar-Joseph M (1999). D-RNA molecules associated with subisolates of the VT strain of Citrus tristeza virus which induce different seedling-yellows reactions. Virus Genes, 19: 513. 